https://doi.org/10.15407/ukrbotj76.04.356

\title{
New records of mushrooms for the mycobiota of Azerbaijan
}

\author{
Elgun H. MUSTAFABAYLI, Dilzara N. AGHAYEVA \\ Institute of Botany, Azerbaijan National Academy of Sciences \\ 40 Badamdar Highway, Baku AZ1004, Azerbaijan \\ a_dilzara@yahoo.com
}

Mustafabayli E.H., Aghayeva D.N. 2019. New records of mushrooms for the mycobiota of Azerbaijan. Ukrainian Botanical Journal, 76(4): 356-361.

Abstract. The article reports data on 24 new records of mushrooms in Azerbaijan. Fungal specimens were collected during 20142018 in Shaki District of Azerbaijan. These are Auriscalpium vulgare, Boletus aereus, B. edulis var. arenarius, B. variipes, Caloboletus radicans, Calocybegambosa, Cantharellussubalbidus, Clavariadelphuspistillaris, Cortinariustriumphans, Hemileccinumdepilatum, Hortiboletus rubellus, Hydnellum concrescens, Inonotusobliquus, Marasmius capillaris, Phaeomarasmius erinaceus, Phallus ravenelii, Ramaria obtusissima, Rheubabariboletus armeniacus, Rubroboletus legaliae, R. lupinus, R. satanas, Russula turci, Suillus collinitus, and Tremella mesenterica. For each specimen, its locality, biotope and collection data are indicated and photographs are provided. Keywords: Azerbaijan, Basidiomycota, Caucasus, fungi, macromycetes, Shaki District

Submitted 15 May 2019. Published 02 September 2019

Мустафабейлі Е.Г., Агаєва Д.Н. 2019. Знахідки нових для мікобіоти Азербайджану видів макроміцетів. Украӥнський ботанічний журнал, 76(4): 356-361.

Інститут ботаніки Національної академії наук Азербайджану

Бадамдарське шосе 40, Баку AZ1004, Азербайджан

Реферат. У статті подано інформацію про поширення 24 видів макроміцетів, нових для Азербайджану. Зразки зібрано протягом 2014-2018 pр. в Шекінському районі. Уперше в країні були виявлені Auriscalpium vulgare, Boletus aereus, B. edulis var. arenarius, B. variipes, Caloboletus radicans, Calocybe gambosa, Cantharellus subalbidus, Clavariadelphus pistillaris, Cortinarius triumphans, Hemileccinum depilatum, Hortiboletus rubellus, Hydnellum concrescens, Inonotus obliquus, Marasmius capillaris, Phaeomarasmius erinaceus, Phallus ravenelii, Ramaria obtusissima, Rheubabariboletus armeniacus, Rubroboletus legaliae, R. lupinus, R. satanas, Russula turci, Suillus collinitus та Tremella mesenterica. Для кожного зразка наведено локалітет, біотоп, дату збору та фотографію.

Ключові слова: Азербайджан, гриби, Кавказ, макроміцети, Шекінський район, Basidiomycota

\section{Introduction}

Dedicated studies of macromycetes of Azerbaijan were launched in the early 1960s. Currently about 2300 specimens of more than 800 taxa of mushrooms collected within the country are deposited at the Mycological Herbarium of the Institute of Botany (BAK), ANAS (Sadiqov, 1972, 2007; Sadiqov, Aghayeva, 2016). That is not a large number of species taking into account rich diversity of microfungi in Azerbaijan. Based on what has been discovered, we can suggest that many species have not been revealed and explored yet. The mushroom diversity in Shaki District studied during several recent years revealed a number of species that are new for the study area, as well as for the country.

Shaki District is located along the Southern Caucasus mountain range. Most of its area is occupied by both coniferous and broadleaf forest ecosystems where oak, beech, birch, hornbeam are dominant tree species. The aim of the article is to present data on new species of mushrooms found in Shaki District, which have not been previously registered in Azerbaijan.

\section{Materials and methods}

Specimens were collected during mycological surveys in Shaki District of Azerbaijan during 2014-2018. All samples were air-dried and deposited at the BAK Herbarium; deposition (inventory) numbers are provided below in the list. The sampling localities and their GPS coordinates are as follows: around the walls of the Gelersen-Gorersen fortress $\left(41^{\circ} 15^{\prime} 48.57^{\prime \prime} \mathrm{N}\right.$, $47^{\circ} 13^{\prime} 40.43^{\prime \prime E}, 1220 \pm 50-60 \mathrm{~m}$ a.s.1.); along Gilehli, hazelnut forest $\left(41^{\circ} 12^{\prime} 14.29^{\prime \prime} \mathrm{N}, 47^{\circ} 12^{\prime} 40.01 " \mathrm{E}, 835-860\right.$

(C) 2019 E.H. Mustafabayli, D.N. Aghayeva. Published by the M.G. Kholodny Institute of Botany, NAS of Ukraine. This is an open access article under the terms of the Creative Commons Attribution License (http://creativecommons.org/licenses/by/4.0/), which permits use, distribution, and reproduction in any medium, provided the original work is properly cited 
$\mathrm{m}$ a.s.1.); Mustafabey oak-beech, chestnut-beech forest (41 ${ }^{\circ} 12^{\prime} \quad 09.06 " \mathrm{~N}, 47^{\circ} 12^{\prime} 52.03^{\prime \prime} \mathrm{E}, 820-930 \mathrm{~m}$ a.s.1.); Naringala pine forest $\left(41^{\circ} 15^{\prime} 33.14^{\prime \prime} \mathrm{N}, 47^{\circ} 13^{\prime} 02.69^{\prime \prime} \mathrm{E}\right.$, $1100 \pm 50-70 \mathrm{~m}$ a.s.1.); Shaki Khans' Palace, included in the UNESCO World Heritage List $\left(41^{\circ} 12^{\prime} 15.17^{\prime \prime} \mathrm{N}\right.$, $47^{\circ} 11^{\prime} 35.83 " \mathrm{\prime}$, $770 \pm 50-70 \mathrm{~m}$ a.s.1.).

Phenological characteristics were recorded and micro-morphological features were examined under the microscope Nikon Eclipse E100, ZEISS (China). Microstructures were mounted in sterile water, statistics included a minimum of 20 measurements. Both size and shape of basidiospores were considered, results were estimated as average of 25 measurements for each specimen. Identification was carried out based on available literature (Wasser, 1980; Arora, 1986; Moser, 1980, 1986; Dudka, Wasser, 1987; Bondartseva, 1998; Horak, 2005; etc.). Nomenclature updates and taxonomic rearrangements are provided as in the Index Fungorum database (http://www.indexfungorum.org).

\section{Results and discussion}

In total, 24 species of the Agaricomycetes belonging to 9 orders and 15 families represent new records for Azerbaijan (Fig. 1). Below we list the species of fungi and discuss peculiarities of some taxa and records.

Agaricales

Cortinariaceae

Cortinarius triumphans Fr. (Fig. 1, A)

Mustafabey oak-beech, chestnut-beech forest, on forest litter. 06.10.2016 (BAK1635).

In the Transcaucasis this species was previously reported from Georgia and Armenia (Key..., 1985).

Inocybaceae

Phaeomarasmius erinaceus (Fr.) Scherff. ex Romagn. (Fig. 1, B)

Mustafabey oak-beech, chestnut-beech forest, on dead wood. 06.10.2016 (BAK1641).

\section{Lyophyllaceae}

Calocybe gambosa (Fr.) Donk (Fig. 1, C)

Naringala pine forest, on forest litter. 22.10.2013 (BAK1557).

In the Transcaucasian region the species has been reported from Georgia and Armenia (Key..., 1985).

\section{Marasmiaceae}

Marasmius capillaris Morgan (Fig. 1, D)

Mustafabey oak-beech, chestnut-beech forest, on dead fallen leaf. 27.07.2016 (BAK1614).

\section{Boletales}

Boletaceae

Boletus aereus Bull. (Fig. 1, E)

Mustafabey oak-beech, chestnut-beech forest, on forest soil. 17.08.2018 (BAK1652).

Boletus edulis var. arenarius H.Engel, Krieglst \& Dermek (Fig. 1, F)

Mustafabey oak-beech, chestnut-beech forest, on forest soil. 25.08.2018 (BAK1665).

Based on our observation, B. edulis var. arenarius differs from $B$. edulis var. edulis by its smaller, reddishyellow cap, as well as a long and curved stipe.

Boletus variipes Peck (Fig. 1, G)

Mustafabey oak-beech, chestnut-beech forest, on forest soil. 25.08.2018 (BAK1664).

Caloboletus radicans (Pers.) Vizzini (Fig. 1, H)

Mustafabey oak-beech, chestnut-beech forest, on forest soil. 18.08.2018 (BAK1649).

Hemileccinum depilatum (Redeuilh) Šutara (Fig. 1, I)

Mustafabey oak-beech, chestnut-beech forest, on forest soil. 25.08.2018 (BAK1667).

Hortiboletus rubellus (Krombh.) Simonini, Vizzini \& Gelardi (Fig. 1, J)

Mustafabey oak-beech, chestnut-beech forest, on forest soil. 25.08.2018 (BAK1653).

Rheubarbariboletus armeniacus (Quél.) Vizzini, Simonini \& Gelardi (Fig. 1, K)

Mustafabey oak-beech, chestnut-beech forest, on forest litter. 10.07.2016 (BAK1596).

We found the form of this species previously known as Xerocomus armeniacus f. luteolus H.Engel \& Antonín; later the species was transferred to the genus Xerocomellus (Quél.) Šutara (2008). Currently, X. armeniacus f. luteolus is synonymised with Rheubarbarioboletus armeniacus. In our observation, forma luteolus differs in color of the stipe and pileus, being greenish-yellow, which is distinct from the reddish Burgundy color of the typical form. Spore size of the species is also slightly different according to literature: $9-15 \times 4-6 \mu \mathrm{m}$ in A. Dermek \& A.Pilát (1974) and 11.6-13.9 (-15.2) $\times$ 5.0-5.8 $\mu \mathrm{m}$ in A.E.Hills (2009). Spores in our measurements were fusiform, light-brown, greenish, with $1-2$ oil drops, $12.5-16.0 \times 4.0-5.5 \mu \mathrm{m}$.

Rubroboletus legaliae (Pilát \& Dermek) Della Magg. \& Trassin. (Fig. 1, L)

Mustafabey oak-beech, chestnut-beech forest, on forest litter. 25.08.2018 (BAK1619).

Rubroboletus lupinus (Fr.) Costanzo \& Gelardi, Simonini \& Vizzini (Fig. 1, M) 

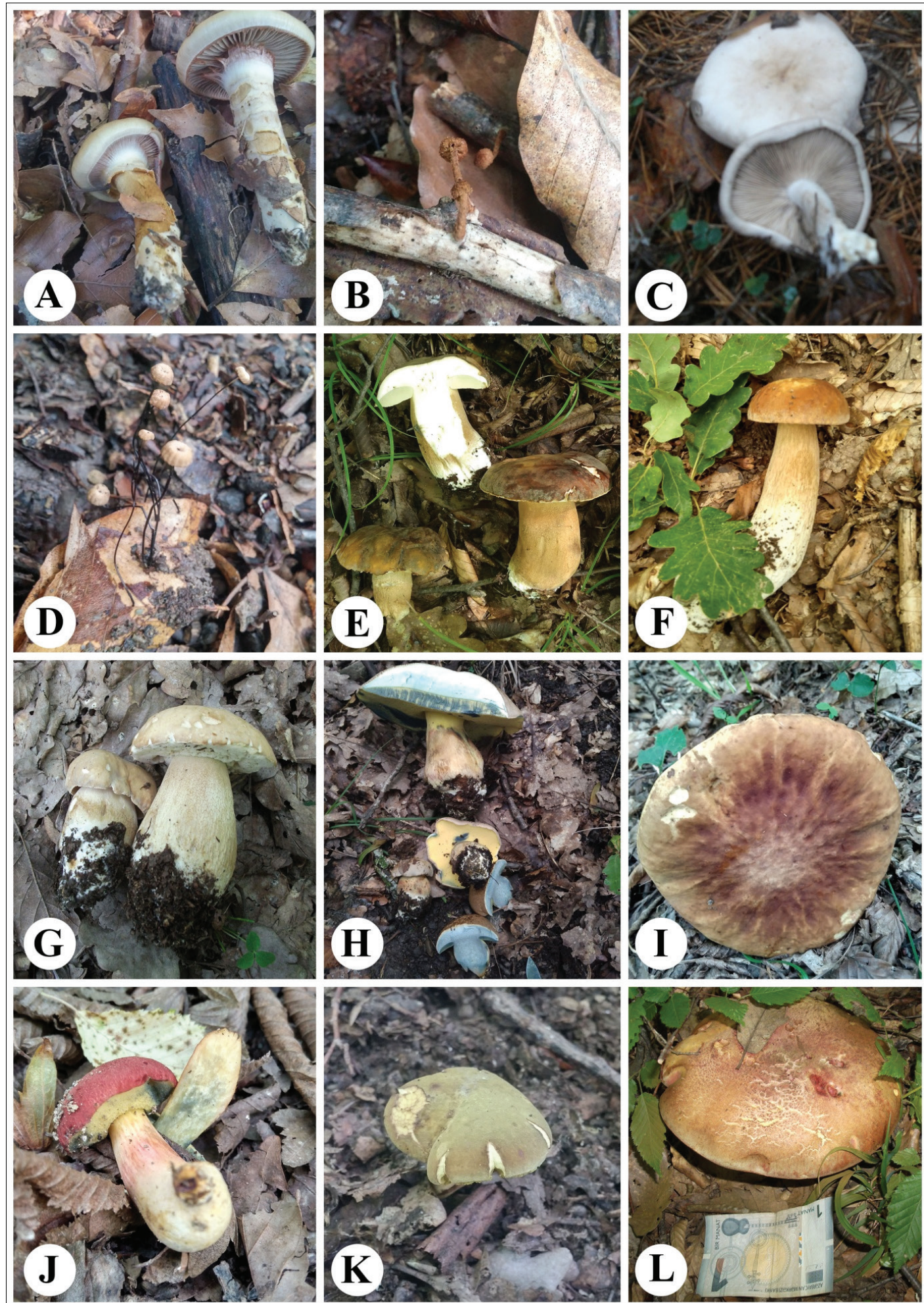

Fig. 1. New records of mushrooms for Azerbaijan (original photos). A: Cortinarius triumphans; B: Phaeomarasmius erinaceus; C: Calocybe gambosa; D: Marasmius capillaris; E: Boletus aereus; F: B. edulis var. arenarius; G: B. variipes; H: Caloboletus radicans; I: Hemileccinum depilatum; J: Hortiboletus rubellus; K: Rheubabariboletus armeniacus; L: Rubroboletus legaliae 

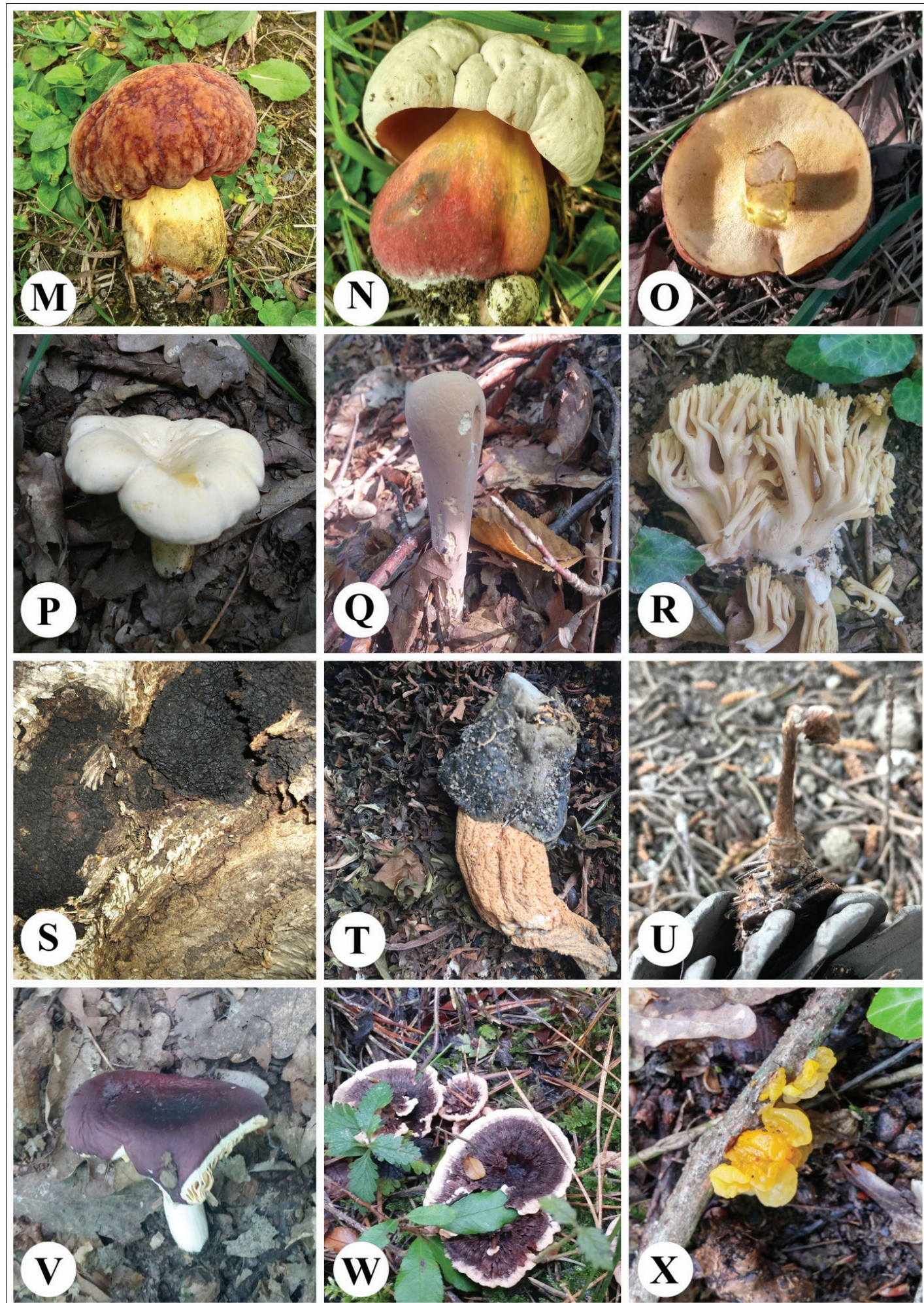

Fig. 1 (continuation). M: Rubroboletus lupinus; N: R. satanas; O: Suillus collinitus; P: Cantharellus subalbidus; Q: Clavariadelphus pistillaris; R: Ramaria obtusissima; S: Inonotus obliquus; T: Phallus ravenelii; U: Auriscalpium vulgare; V: Russula turci; W: Hydnellum concrescens; X: Tremella mesenterica 
Mustafabey oak-beech, chestnut-beech forest, on forest litter. 18.08.2018 (BAK1659).

Rubroboletus satanas (Lenz) Kuan Zhao \& Zhu L. Yang (Fig. 1, N)

Gilehli, hazelnut forest, on forest litter. 25.08.2018 (BAK1650).

Suillaceae

Suillus collinitus (Fr.) Kuntze (Fig. 1, O)

Around the Shaki Khans' Palace fortress walls, coniferous forest, on soil. 20.11.2016 (BAK1600).

Cantharellales

Cantharellaceae

Cantharellus subalbidus A.H.Sm. \& Morse (Fig. 1, P) Mustafabey oak-beech, chestnut-beech forest, on soil. 23.07.2017 (BAK1631).

\section{Gomphales}

Clavariadelphaceae

Clavariadelphus pistillaris (L.) Donk (Fig. 1, Q)

Mustafabey oak-beech, chestnut-beech forest, on soil. 06.10.2016 (BAK1620).

Gomphaceae

Ramaria obtusissima (Peck) Corner (Fig. 1, R)

Mustafabey oak-beech, chestnut-beech forest, on soil. 26.11.2015 (BAK1630).

Hymenochaetales

Hymenochaetaceae

Inonotus obliquus (Fr.) Pilát (Fig. 1, S)

Along the Gelersen-Görersen fortress walls, on Betula sp. 23.07.2017 (BAK1657).

Phallales

Phallaceae

Phallus ravenelii Berk. \& M.A. Curtis (Fig. 1, T)

Around the Shaki Khans' Palace fortress walls, coniferous forest, on soil. 25.07.2017 (BAK1621).

Russulales

Auriscalpiaceae

Auriscalpium vulgare Gray (Fig. 1, U)

Naringala pine forest, on cone of Pinus sylvestris. 08.05.2017 (BAK1647).

Russulaceae

Russula turci Bres. (Fig. 1, V)

Mustafabey oak-beech forest, on forest soil. 16.08.2016. (BAK1615).

In the Transcaucasian region it has been reported from Georgia (Key..., 1985).

\section{Thelophorales}

Bankeraceae

Hydnellum concrescens (Pers.) Banker (Fig. 1, W)

Naringala pine forest, among mosses in coniferous forest. 26.11.2015 (BAK1634).

\section{Tremellales}

Tremellaceae

Tremella mesenterica Retz. (Fig. 1, X)

Naringala pine forest, on dead pine branches. 27.07.2017 (BAK1627).

All identified taxa can be subdivided into three ecological groups: symbiotrophs, humus saprotrophs, and xylotrophs. Most of the species are symbiotrophs, including Cortinarius triumphans (Cortinariaceae) and Calocybe gambosa (Lyophyllaceae) from the order Agaricales. The highest number of species are representatives of the order Boletales: Boletus aereus, B. edulis var. arenarius, B. variipes, Caloboletus radicans, Hemileccinum depilatum, Hortiboletus rubellus, Rheubarbariboletus armeniacus, Rubroboletus legaliae, $R$. lupinus, and $R$. satanas (Boletaceae) and one more species - Suillus collinitus (Suillaceae). Cantharellus subalbidus (Cantharellaceae), Clavariadelphus pistillaris (Clavariadelphaceae), Hydnellum concrescens (Bankeraceae), and Russula turci (Russulaceae) belong to the same ecological group. These fungi are associated with some species of trees, such as Quercus iberica M.Bieb., Castanea sativa Mill., Fagus sylvatica L., Carpinus betulus L., Ulmus minor Mill., and Pinus sylvestris L.

Humus saprotrophs include Ramaria obtusissima (Gomphaceae), Phallus ravenelii (Phallaceae).

Xylotrophs can be divided into three subgroups: fungi occurring on cones, leaves, and stems. Phaeomarasmius erinaceus (Inocybaceae) was recorded on dead wood of hornbeam and beech trees. Marasmius capillaris was found on dead fallen leaves of oak and beech, Auriscalpium vulgare - on cones of dead pine trees and Tremella mesenterica - on stem of broadleaf tree species. Parasitic Inonotus obliquus (Hymenochaetaceae), a widely distributed species in the study area, was identified on a birch tree.

Fungal diversity studies rely on the data about collected samples, images and identified fungal taxa in certain area. This information provides a source for scientific research and management of natural resources for the mutual benefit of humans and nature. The reported research represents a new contribution to the existing data on mushroom diversity of Azerbaijan. 


\section{REFERENCES}

Aghayeva D.N., Sadiqov A.S. 2009. Proceedings of the Institute of Botany ANAS (Azerbaijan National Academy of Sciences), 29: 176-183. [Ağayeva D.N., Sadıqov A.S. 2009. Böyük Qafqaz və Talışdan toplanılmıș müxtəlif ekoloji qruplara aid makromisetlər. AMEA Botanika Institutunun elmi asarlari, 29: 176-183].

Arora D. 1986. Mushrooms Demystified: A Comprehensive Guide to the Fleshy Fungi. 2nd ed. Berkeley: Ten Speed Press, 959 pp. [pp. 615].

Dermek A., Pilát M. 1974. Poznávajne huby. Veda: Vydavatelstvo Slovenskej Akadémie Vied, $256 \mathrm{~s}$.

Bondartseva M.A. 1998. Handbook of fungi of Russia. Order Aphillophorales, issue 2. St. Petersburg: Nauka, 391 pp. [Бондарцева М.А. 1998. Определитель грибов России. Порядок Афиллофоровые, вып. 2. Санкт-Петербург: Наука, 391 с.].

Dudka I.A., Wasser S.P. 1987. Griby. Spravochnik mikologa i gribnika. Kiev: Naukova Dumka, 534 pр. [Дудка I.A., Вассер С.П. 1987. Грибы. Справочник миколога и грибника. Киев: Наукова думка, 534 с.].

Grunert G., Grunert B. 2002. Fungi. Moscow: Astrel, 287 pр. [Грюнерт Г., Грюнерт Б. 2002. Грибы. Москва: Астрель, 287 с.].

Hills A.E. 2009. The genus Xerocomus. A personal view, with a key to the British species. Field Mycology, 9(3): 77-96.

Key to agaric mushrooms of Transcaucasica. 1985. Ed. I.G. Nakhutsrishvili. Tibilisi: Mecniereba [Metsniereba], 264 pp. [Определитель агарикальных грибов Закавказья. Ред. И.Г. Нахуцришвили. Тбилиси: Мецениереба, 264 с.].

Moser M. 1967. Die Röhrlinge und Blätterpilze (Agaricales). In: Kleine Kryptogamenflora, Bd II b/2. Jena: G. Fischer, $443 \mathrm{~S}$.
Moser M. 1986. Guida alla determinazione dei fungi (Polyporales, Boletales, Agaricales, Russulales). Trento: Saturnia, $565 \mathrm{pp}$.

Pilát A. 1969. Houby Československa ve svém životnim prostředi. Praha: Academia Nakladatelstvǐ Ceskoslovenské Academie Véd, 267 s.

Sadiqov A.S. 1972. Transaction of Azerbaijan National Academy of Sciences, 1: 32-36. [Садыхов A.C. 1972. Новые для Азербайджана агариковые грибы. Известия АН Азербайджанской ССР. Серия биологических наук, 1: 32-36].

Sadiqov A.S. 2007. Edible and poisonous mushrooms of Azerbaijan. Baku: Elm, 109 pp. [Azarbaycanın yemali və zahərli göbalaklari. Bakı: Elm, 109 s.].

Sadiqov A.S., Aghayeva D.N. 2016. Proceedings of the Azerbaijan National Academy of Sciences (Biological and Medical Sciences), 71(2): 43-49. [Sadıqov A.S., Ağayeva D.N. 2016. Azərbaycan üçün yeni makromisetlor. AMEA-nın Xabarlari (biologiya va tibb elmlari), 71(2): 43-49].

Sutara J. 2008. Xerocomus s. 1. in the light of the present state of knowledge. Czech Mycology, 60(1): 29-62.

Wasser S.P. 1980. Flora of fungi of Ukraine. Gilled mushrooms (Agaricales). Kiev: Naukova Dumka, 328 pp. [Bacсер С.П. 1980. Флора грибов Украины. Агариковые грибы. Киев: Наукова думка, 328 с.].

Zerova M.Ya., Sosin P.E., Rozhenko G.L. 1979. Identification manual of fungi of Ukraine, vol. 5, book 2. Boletales, Strobilomycetales, Tricholomatales, Entolomatales, Russulales, Agaricales, Gasteromycetes. Kyiv: Naukova Dumka, 564 pp. [Зерова М.Я., Сосін П.Е., Роженко Г.Л. 1979. Визначник грибів України, т. 5, книга 2. Болетальні, стробіломіцетальні, трихоломатальні, ентоломатальні, русулальні, агарикальні, гастероміиети. Київ: Наукова думка, 564 с.].

Recommended for publication by V.P. Heluta 